\title{
Effect of Chloramphenicol on Protein and Nucleic Acid Synthesis by Shigella flexneri
}

\author{
By R. B. YEE, SYLVLA PAN AND H. M. GEZON \\ Graduate School of Public Health, Lniversity of Pittsburgh, Pittsburgh 18, \\ Pennsylvania, U.S.A.
}

(Receized 31 July 1961)

\begin{abstract}
SLMMARY
Resting organisms of Shigella flexneri 3 were able to synthesize protein and nucleic acids in a chemically defined medium. Protein synthesis was markedly inhibited while ribonucleic acid (RNA) synthesis was stimulated by low concentrations of chloramphenicol; deoxyribonucleic acid syn. thesis was inhibited slightly. Neither glycine, L-phenylalanine nor L-tyrosine annulled the action of the antibiotic. Inhibition of protein synthesis and stimulation of RNA synthesis in resting organisms of a chloramphenicol-resistant mutant of $S$. flexneri 3 was observed only in the presence of high concentrations of chloramphenicol. The results presented in this paper show that chloramphenicol suppresses the growth of $S$. flexneri 3 by interfering with the synt suggests that chloramphenicol may exert its inhibitory action by promoting the formation of RNA with altered biological activity.
\end{abstract}

\section{INTRODLCTION}

The exact biochemical nature of the mode of action of chloramphenicol on bacteria is not yet known. Investigations have shown the compound is a strong inhibitor of protein synthesis (Gale \& Folkes, 1953; Wisseman, Smadel, Hahn \& Hopps, 1954; Pardee \& Prestidge, 1956; Bernlohr \& Webster, 1958). However, there is a lack of agreement about the effect of the drug on nucleic acid synthesis. Gale \& Folkes (1953) showed that chloramphenicol stimulated nucleic acid production in Staphylococcus aureus. Wisseman et al. (1954) observed no effect in Escherichia coli strain B. Harrington (1958), on the other hand, reported that a slight enhancement of nucleic acid synthesis accompanied the chloramphenicol inhibition of protein synthesis in $E$. coli strain B. Pardee \& Prestidge (1956) also with E. coli strain $\mathbf{B}$ found that low concentrations of the chloramphenicol did not suppress the production of nucleic acid, whereas high concentrations markedly inhibited the formation of deoxyribonucleic acid (DNA), and, to a lesser extent, ribonucleic acid (RNA). With Azotobacter agilis, Bernlohr \& Webster (1958) showed that high concentrations of chloramphenicol markedly depressed protein, DNA and RNA synthesis while lower amounts inhibited only protein and DNA production.

Although chloramphenicol is of major importance in the therapy of shigellosis, studies on its effect on the metabolism of shigellas have not as yet been reported. An investigation has been begun to determine the mechanism of chloramphenicol action in a strain of Shigella flexneri 3. The effects of chloramphenicol on protein and in particular nucleic acid synthesis by this organism in a chemically defined medium has been studied and the results are presented in this paper. 


\section{METHODS}

Cultures. Shigella flexneri 3 strain B-1003 was used. The origin of the organism and the maintenance of the reference stock culture were described previously (Pan, Yee \& Gezon, 1957). The growth of this strain was inhibited by 2-4 $\mu \mathrm{g}$. chloramphenicol $/ \mathrm{ml}$. as determined by the tube dilution method. The Szybalski gradient plate technique (Bryson \& Szybalski, 1952) was used to isolate a chloramphenicol-resistant mutant of strain B-1003. Growth of the mutant was inhibited by $50-60 \mu \mathrm{g}$. chloramphenicol $/ \mathrm{ml}$.

Cultivation of organism. The organisms were cultured in a defined medium (DM) containing the following g./l. medium: $3.53 \mathrm{KH}_{2} \mathrm{PO}_{4} ; 5.78 \mathrm{Na}_{2} \mathrm{HPO}_{4} ; 5.00$ $\mathrm{NaCl} ; 0.24 \mathrm{MgSO}_{4} .7 \mathrm{H}_{2} \mathrm{O} ; 2.50 \mathrm{D}$-glucose as an energy and carbon source; $2 \cdot 50$ $\mathrm{NH}_{4} \mathrm{H}_{2} \mathrm{PO}_{4}$ as sole nitrogen source. The medium also contained $0.01 \mu \mathrm{g}$. nicotinamide/ml. This defined medium will be referred to as ammonium phosphate DM. For metabolic experiments, a loopful of growth from an $18 \mathrm{hr}$. ammonium phosphate DM slope culture was inoculated into the liquid DM. The liquid cultures were acrated continuously by vigorous shaking on a Burrell wrist action shaker. Incubation was carricd out at $37^{\circ}$ for $18 \mathrm{hr}$.

To cultivate the chloramphenicol-resistant mutant, the organisms were transferred from a stock semi-solid DM stab culture to an ammonium phosphate DM agar slope. After incubation for $18 \mathrm{hr}$. at $37^{\circ}$, a loopful of the slope culture was streaked on a Szybalski gradient plate containing chloramphenicol. The most resistant organisms on the gradient plate were then transferred to an ammonium phosphate DM agar slant containing $20 \mu \mathrm{g}$. chloramphenicol/ml. The resulting growth was resuspended in $2 \mathrm{ml}$. DM containing $\mathrm{L}$-aspartic acid instead of $\mathrm{NH}_{4} \mathrm{H}_{2} \mathrm{PO}_{4}$ as nitrogen source and inoculated into $400-500 \mathrm{ml}$. of the DM containing $20 \mu \mathrm{g}$. chloramphenicol $/ \mathrm{ml}$. Aspartic acid DM was used since resting organisms which had been grown in this medium exhibited higher degrees of protein and nucleic acid synthesis than ones grown in ammonium phosphate DM. Incubation of the culture was the same as that for the parent strain.

Preparation of organisms. After incubation, the organisms were harvested by centrifugation and washed three times with phosphate buffered saline ( $\mathrm{pH} \mathrm{6.9)}$. For growth experiments, the organisms were used immediately; for resting cell experiments, they were aerated at $37^{\circ}$ for $2-3 \mathrm{hr}$. by shaking in a Dubnoff metabolic shaking incubator, washed once, resuspended in saline, and stored overnight at $5^{\circ}$. The organisms were again acrated for $1 \mathrm{hr}$., centrifuged and washed once in buffered saline; these will be referred to as resting organisms. Multiplication in defined media during the period of the experiment was at a minimum.

Reaction system. Study of the effect of chloramphenicol on protein and nucleic acid synthesis in defined media was carried out with growing and with non-growing organisms. The organisms were suspended in a solution of $\mathrm{KH}_{2} \mathrm{PO}_{4}, \mathrm{Na}_{2} \mathrm{HPO}_{4}$, $\mathrm{NaCl}$ and nicotinamide; the concentration was adjusted so that the suspension gave $10 \%$ light transmittance at $425 \mathrm{~m} \mu$ with a light path of $18 \mathrm{~mm}$. in a Coleman Model $6 \mathrm{~B}$ spectrophotometer. This suspension was used in the experiments with non-growing organisms while in the experiments with growing organisms a $1 / 10$ dilution of the suspension in the salt solution was used. Thirty ml. of suspension was mixed with $15 \mathrm{ml}$. of solution containing $\mathrm{NH}_{4} \mathrm{H}_{2} \mathrm{PO}_{4}$ or a specified amino acid, 
D-glucose and $\mathrm{MgSO}_{4} \cdot 7 \mathrm{H}_{2} \mathrm{O}$. The final concentration of all the compounds was the same as that in the defined media used for growth. The organisms were incubated at $37^{\circ}$ in a Dubnoff metabolic shaking incubator; duplicate samples were removed for analysis. Nucleic acids and proteins were precipitated with cold $5 \%(w / v)$ trichloroacetic acid, sedimented by centrifugation at $2700 \mathrm{~g}$ for $40 \mathrm{~min}$. at $0^{\circ}$ and washed once with cold $5 \%(\mathrm{w} / \mathrm{v})$ trichloroacetic acid. The precipitates for protein analysis were dissolved in $\mathrm{N}-\mathrm{NaOH}$. The precipitates for nucleic acid determinations were extracted by the method of Gale \& Folkes (1953). For the estimation of ammonia utilization, the organisms were removed by centrifugation at $0^{\circ}$ and the supernatant fluid analysed. Each experiment was replicated twice or more. The data presented in the figures are the results of single experiments.

Analytical methods. Ammonia was determined by nesslerization (Umbreit, Burris \& Stauffer, 1957); protein by the method of Lowry, Rosebrough, Farr \& Randall (1951); RNA by the Meijbaum technique (Colowick \& Kaplan, 1957); DNA by the Burton modification of the Dische technique (Burton, 1956) and total nucleic acid by measuring the absorption of the extracts at $260 \mathrm{~m} \mu$. The Beckman model DI spectrophotometer was used in all the analyses. Numbers of viable organisms were determined by the plate count technique.

\section{RESULTS}

The results of experiments with growing cultures of Shigella flexneri 3 showed that multiplication, ammonia assimilation and protein DNA and RNA synthesis were suppressed by low concentrations of chloramphenicol. However, it could not be concluded from these findings that the inhibition of multiplication was the result of interference with the metabolic processes; the decrease in metabolic activity might merely reflect a decrease in multiplication. To test this hypothesis, non-multiplying or at least slowly multiplying preparations of organisms, designated resting organisms, were used. There was no detectable increase in numbers of viable organisms during the first $2 \mathrm{hr}$. of incubation in the defined media, although by this time maximum increases in protein and nucleic acid were attained (Fig. 1). Studies on ammonia assimilation by resting organisms in ammonium phosphate defined medium showed that the assimilation was not affected by chloramphenicol, of which concentrations as high as $100 \mu \mathrm{g} . / \mathrm{ml}$. were used. The previously observed inhibition of ammonia assimilation in growing cultures of $S$. flexneri 3 thus appears to be the result rather than the cause of the suppression of multiplication.

The ability of the resting organisms to synthesize protein and nucleic acids in the presence of various nitrogen sources in a mineral salts glucose base is shown in Fig. 1. The relatively simple nutritional requirements of Shigella flexneri was indicated by the results. The highest increases in protein and nucleic acids were obtained when the organisms were provided with either ammonium phosphate or L-aspartic acid. Although the degree of protein synthesis was the same in the presence of these two compounds, considerably more nucleic acids were produced when L-aspartic acid served as nitrogen source. Appreciably less protein synthesis and no detectable nucleic acid synthesis was observed with the other nitrogenous compounds. 
The effect of low concentrations of chloramphenicol on protein and nucleic acid synthesis in aspartic acid DM is shown in Fig. 2; similar results were obtained with ammonium phosphate DM. The formation of protein was markedly depressed by chloramphenicol; there was almost complete inhibition with $2 \cdot 0 \mu \mathrm{g}$. $/ \mathrm{ml}$. In
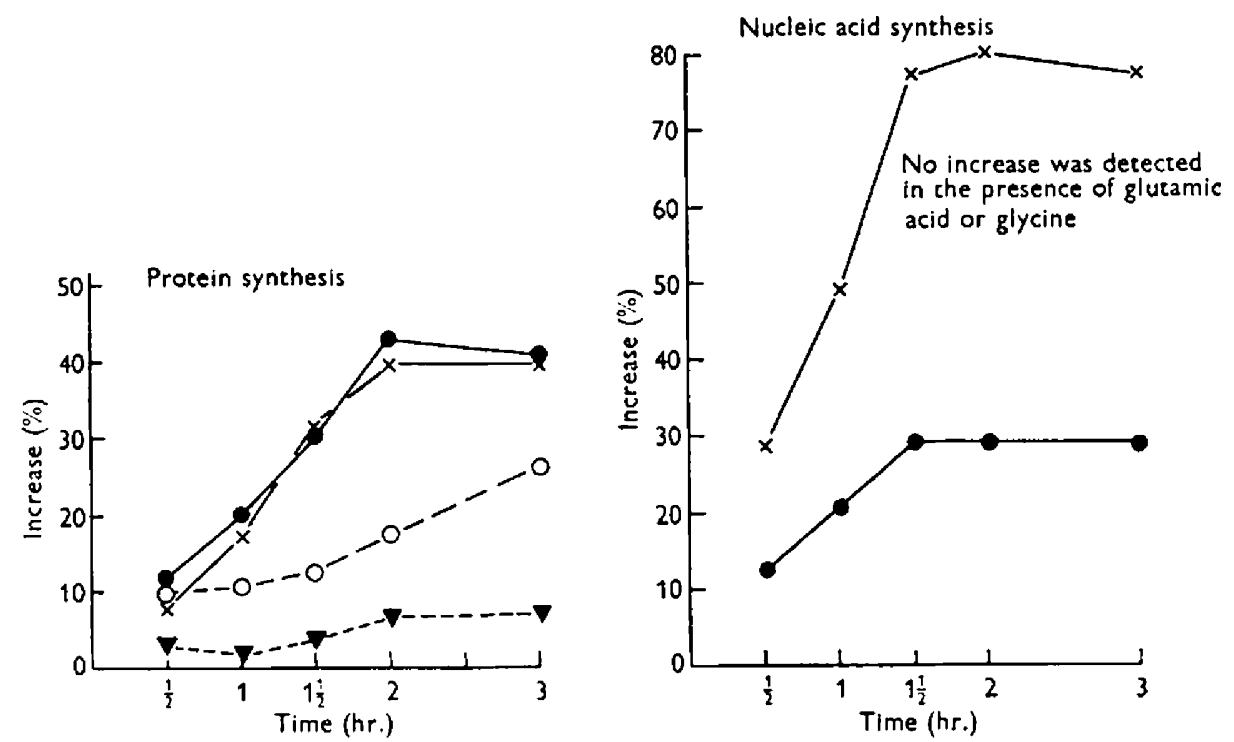

Fig. 1. Synthesis of protein and nucleic acid by resting organisms of Shigella flexneri 3 B-1003 in the presence of different nitrogen compounds: (O) $\mathrm{NH}_{4} \mathrm{H}_{8} \mathrm{PO}_{4} ;(x)$ L-aspartic acid; (O) L-glutamic acid; ( $\nabla$ ) glycine
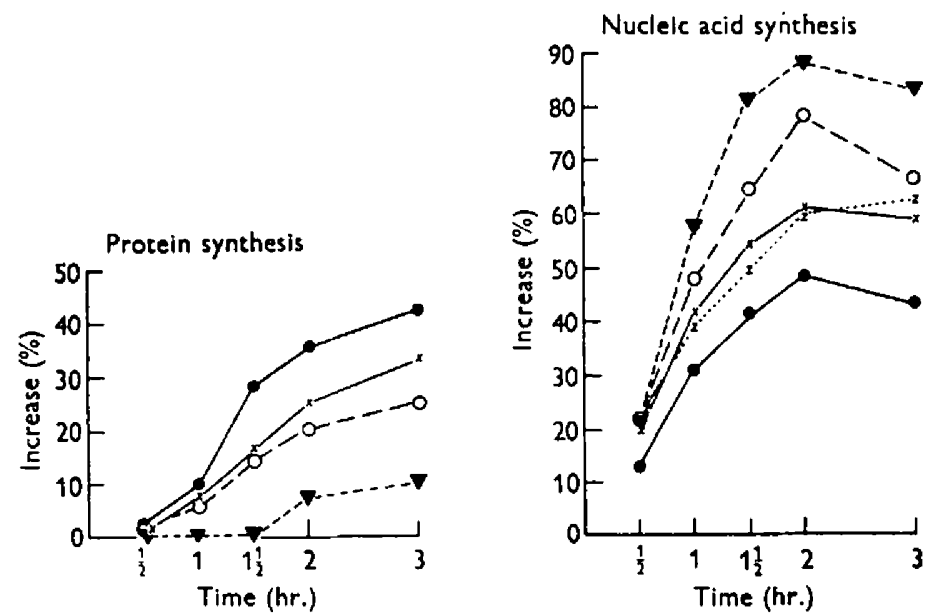

Fig. 2. Effect of chloramphenicol on protein and nucleic acid synthesis by resting Shigella flexneri 8 B-1008 in aspartic acid defined medium. Chloramphenicol concentrations ( $\mu \mathrm{g} . / \mathrm{ml}$.) used were: (O) $0 ;(x) 0.5 ;(O) 1 ;(\nabla) 2 ;(z) 10$.

contrast to the observed action on protein production, nucleic acid synthesis was markedly stimulated by chloramphenicol; in the range of $0 \cdot 5-2 \cdot 0 \mu \mathrm{g}$. chlorampheni$\mathrm{col} / \mathrm{ml}$., the addition of increasing concentrations resulted in greater stimulation, 
whereas beyond these concentrations the degree of stimulation was decreased. Analyses of the extracts by the Meijbaum technique showed that the observed increase was the result of stimulation of RNA synthesis. Low concentrations of chloramphenicol appeared to depress slightly the rate of DNA formation.

Harrington (1958) reported that the excretion of $260 \mathrm{~m} \mu$ absorbing substances by Escherichia coli was increased considerably in the presence of $1.0 \mu \mathrm{g}$. chloramphenicol $/ \mathrm{ml}$. In contrast, concentrations of $0.5-2.0 \mu \mathrm{g} . / \mathrm{ml}$. had no effect on the rate of excretion of $260 \mathrm{~m} \mu$ absorbing substances by resting Shigella flexneri 3 in aspartic acid DM. Various investigators (Mentzer, Meunier \& Molho-LaCroix, 1950; Woolley, 1950; Foster \& Pittillo, 1953) reported that glycine, L-phenylalanine or L-tyrosine annulled the growth inhibitory action exerted by chloramphenicol
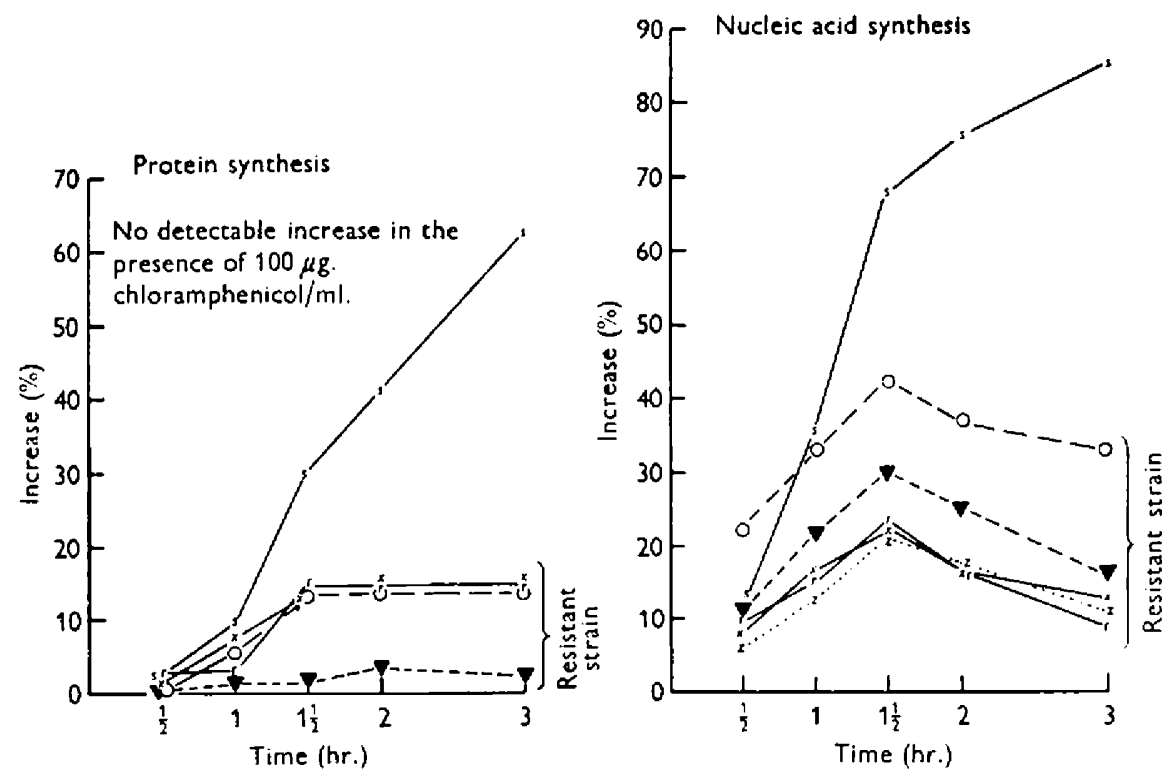

Fig. 8. Effect of chloramphenicol on protein and nucleic acid synthesis by resting organisms of a chloramphenicol-resistant mutant of Shigella flexneri 3 B-1003 in aspartic acid defined medium. Chloramphenicol concentrations $(\mu \mathrm{g} . / \mathrm{ml}$.) used were: $(r) 0 ;(\times) 2$; (O) $25 ;(\nabla) 50 ;(z) 100$. The results with a chloramphenicol-sensitive strain $(s)$ are included for comparison.

against $E$. coli. They suggested that the compound acts as an amino acid antagonist. Experiments were carried out to determine the effect of $0.125 \%(\mathrm{w} / \mathrm{v})$ of each of these amino acids on the action of chloramphenicol against protein and nucleic acid synthesis by resting $S$. flexneri 3 metabolizing in L-aspartic acid DM. Chloramphenicol concentrations of $1.0 \mu \mathrm{g}$. and $4.0 \mu \mathrm{g} . / \mathrm{ml}$. (causing about $50 \%$ or complete inhibition of protein synthesis, respectively) were used. None of these amino acids demonstrated an antagonistic action against the effects of chloramphenicol. These results are similar to those reported by Hopps et al. (1956). Chloramphenicol does not appear to suppress protein synthesis by acting as an amino acid antagonist.

Protein synthesis by chloramphenicol-resistant mutants would be expected to be insensitive to low concentrations of the antibiotic if the synthesis were the 
site of chloramphenicol inhibition. With this in mind, experiments with resting organisms of a resistant mutant of Shigella flexneri strain B-1003 were performed. The results are shown in Fig. 3;2 $\mu$ g. chloramphenicol $/ \mathrm{ml}$. which markedly inhibited protein synthesis and stimulated RNA production by the wild type had no effect on the resistant mutant. A concentration of $50 \mu \mathrm{g}$. chloramphenicol/ml., which approaches that required for growth inhibition of the mutant, was necessary for the depression of protein synthesis and the stimulation of RNA synthesis. The results in Fig. 3 also show that the synthesizing activity of the resistant organisms was considerably lower than that of the wild type. This finding was not unexpected since it had been observed that cultures of the resistant mutant grew slower than those of the wild type.

\section{DISCUSSION}

The findings presented here suggest that, as in Staphylococcus aureus and Escherichia coli, chloramphenicol suppresses the multiplication of Shigella flexneri 3 B-1003 through interference with protein synthesis. Further support for this conclusion is provided by the results of experiments with the chloramphenicol-resistant mutant. The increased resistance of multiplication to chloramphenicol was accompanied by a similar increase in the resistance of protein synthesis by the mutant. The observed stimulation of RNA synthesis by chloramphenicol in $S$. flexneri 3 B-1003 is in agreement with the findings of Gale \& Folkes (1953) with $S$. aureus but not with those of Wisseman et al. (1954) who stated they were unable to demonstrate stimulation in $E$. coli. Thus the chloramphenicol may differ in its action with different species. Another possible explanation for the lack of agreement may be the use of non-multiplying organism suspensions in the present study and that of Gale \& Folkes and the use of rapidly growing organisms by Wisseman et al. This was suggested by Harrington (1958).

The stimulation of RNA synthesis in resting Shigella flexneri 3 B-1003 suggests that chloramphenicol may suppress the formation of protein by altering synthesis of the nucleic acid. As a result, RNA which cannot participate in protein synthesis may be produced or, as proposed by Gale (1958) and Ramsey (1958), the drug may change or interfere with the function of RNA. Pardee, Paigen \& Prestidge (1957), Niedhardt \& Gros (1957) and Nomura \& Watson (1959) presented evidence which suggests that RNA formed by Escherichia coli in the presence of chloramphenicol is different from that produced in the absence of the compound. Also, Horiuchi, Horiuchi \& Mizuno (1959) reported that RNA synthesized by $E$. coli in the presence of chloramphenicol did not participate in the formation of protein in intact organisms.

This investigation was carried out under the sponsorship of the Commission on Enteric Infections, Armed Forces Epidemiological Board, and financially supported by the Surgeons General, Department of the Army and Department of the Navy. We are grateful to Parke, Davis and Co. for a generous supply of chloramphenicol. We also wish to thank Mr F. Erdlejac and Mr J. McElligott for their technical assistance. 


\section{REFERENCES}

Bersionr, R. W. \& Webster, G. C. (1958). Effect of chloramphenicol on protein and nucleic acid metabolism in Azotobacter agilis. J. Bact. 76, 2333.

Bryson, V. \& Szybalski, W. (1952). Microbial selection. Science, 116, 45.

Burton, K. (1956). A study of the conditions and mechanisms of the diphenylamine reaction for the colorimetric estimation of deoxyribonucleic acid. Biochem. J. 62, 315 .

Colowick, S. P. \& Kaplan, N. O. (1957). Methods in Enzymology, vol. 3. New York: Academic Press Inc.

Foster, J. W. \& Pitrifiso, R. F. (1953). Metabolite reversal of antibiotic inhibition, especially reversal of aureomycin inhibition by riboflavin. $J$. Bact. 66, 478 .

Gale, E. F. \& Folkes, J. P. (1953). The assimilation of amino acids by bacteria. 15. Actions of antibiotics on nucleic acid and protein synthesis in Staphylococcus aureus. Biochem. J. 53, 493.

GaLE, E. F. (1958). Specific inhibitors of protein synthesis. In The Strategy of Chemotherapy. Symp. Soc. gen. Microbiol. 8, 212.

Harrington, M. G. (1058). The action of chloramphenicol on protein and nucleic acid synthesis by Escherichia coli strain B. J. gen. Microbiol. 18, 767.

Hopps, H. F., Wisseman, C. L., Jr., Hahn, F. F., Smader, J. E. \& Ho, R. (1956). Mode of action of chloramphenicol. 4. Failure of selected natural metabolites to reverse antibiotic action. J. Bact. 72, 561 .

Horiuchi, T., Horiuchi, S. \& Mizuno, D. (1959). Non-participation in protein synthesis of the RNA synthesized in the presence of chloramphenicol in Escherichia coli. J. med. Sci. $12,99$.

Lowry, O. II., Rosebrough, N. J., Farr, A. L. \& Randali, R. J. (1951). Protein measurement with the Folin phenol reagent. J. biol. Chem. 193, 265.

Mentzer, C., Meunier, P. \& Moumo-LaCroix, L. (1950). Faits de synergie et d'antagonisme entre la chloromycétine et divers amino-scids vis-à-vis de cultures d' $E$. coli. C.R. Acad. Sci., Paris, 230, 241.

NiEdHardT, F. C. \& Gros, F. (1957). Metabolic instability of the ribonucleic acid synthesized by Escherichia coli in the presence of chloromycetin. Biochim. biophys. Acta, 25, 513.

Nomura, M. \& Watson, J. D. (1959). Ribonucleoprotein particles with chloromycetin inhibited Escherichia coli. J. mol. Biol. 1, 204.

Pan, S. F., Yef, R. \& Gezon, H. M. (1957). Studies on the metabolism of Shigella. I. The occurrence of a tricarboxylic acid cycle in Shigella flexneri. J. Bact. 73, 402.

Pardee, A. B. \& Prestidge, L. S. (1956). The dependence of nucleic acid synthesis on the presence of amino acids in Escherichia coli. J. Bact. 71, 6 r7.

Pardee, A. B., Paigen, K. \& Prestidge, L. (1957). A study of the ribonucleic acid of normal and chloromycetin-inhibited bacteria by zone electrophoresis. Biochim. biophys. Acta, 23, 162.

Ramsey, H. H. (1958). Protein synthesis as a basis for chloramphenicol-resistance in Staphylococcus aureus. Nature, Lond. 182, 602.

Umbreit, W. W., Burris, R. H. \& StaufFen, J. H. (1957). Manometric Techniques. Minneapolis: Burgess Publishing Co.

Wisseman, C. L., Jr., Smadel, J. E., Hafi, F. E. \& Hopps, H. E. (1954). Mode of action of chloramphenicol. 1. Action of chloramphenicol on assimilation of ammonia and on synthesis of proteins and nucleic acids in Escherichia coli. J. Bact. 67, 662.

Woourey, D. W. (1950). A study of non-competitive antagonism with chloromycetin and related analogues of phenylalanine. J. biol. Chem. 185, 293. 